\title{
Article
}

\section{Social sustainability in developing country suppliers}

\author{
Anisul Huq, Fahian, Stevenson, Mark and Bell, Marta \\ Available at http://clok.uclan.ac.uk/28024/ \\ Anisul Huq, Fahian, Stevenson, Mark and Bell, Marta (2014) Social \\ sustainability in developing country suppliers. International Journal of \\ Operations \& Production Management, 34 (5). pp. 610-638. ISSN 0144-3577
}

It is advisable to refer to the publisher's version if you intend to cite from the work. http://dx.doi.org/10.1108/IJOPM-10-2012-0467

For more information about UCLan's research in this area go to

http://www.uclan.ac.uk/researchgroups/ and search for < name of research Group>.

For information about Research generally at UCLan please go to

http://www.uclan.ac.uk/research/

All outputs in CLoK are protected by Intellectual Property Rights law, including Copyright law. Copyright, IPR and Moral Rights for the works on this site are retained by the individual authors and/or other copyright owners. Terms and conditions for use of this material are defined in the policies page.

\section{CLoK}

Central Lancashire online Knowledge www.clok.uclan.ac.uk

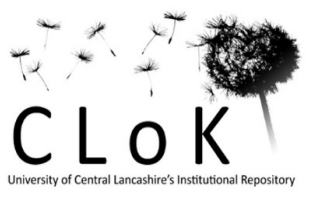




\section{Social Sustainability in Developing Country Suppliers: An Exploratory Study in the Ready Made Garments Industry of Bangladesh}

Fahian Anisul Huq, Mark Stevenson, and Marta Zorzini

\begin{tabular}{|c|c|}
\hline Name: & Fahian Anisul Huq \\
\hline Institution: & Lancaster University \\
\hline \multirow[t]{5}{*}{ Address: } & Department of Management Science \\
\hline & Lancaster University Management School \\
\hline & Lancaster University \\
\hline & LA1 4YX \\
\hline & U.K. \\
\hline E-mail: & f.huq@lancaster.ac.uk \\
\hline Name: & Dr Mark Stevenson \\
\hline Institution: & Lancaster University \\
\hline \multirow[t]{5}{*}{ Address: } & Department of Management Science \\
\hline & Lancaster University Management School \\
\hline & Lancaster University \\
\hline & LA1 4YX \\
\hline & U.K. \\
\hline E-mail: & m.stevenson@lancaster.ac.uk \\
\hline Tel: & 00441524593847 \\
\hline Name: & Dr Marta Zorzini \\
\hline Institution: & Lancaster University \\
\hline \multirow[t]{5}{*}{ Address: } & Department of Management Science \\
\hline & Lancaster University Management School \\
\hline & Lancaster University \\
\hline & LA1 4YX \\
\hline & U.K. \\
\hline E-mail: & m.zorzini@lancaster.ac.uk \\
\hline
\end{tabular}

Keywords: Social Sustainability; Developing Country Suppliers; Ready Made Garments Industry; Bangladesh; Exploratory Case Study; Transaction Cost Economics. 


\title{
Social Sustainability in Developing Country Suppliers: An Exploratory Study in the Ready Made Garments Industry of Bangladesh
}

\begin{abstract}
Purpose: To investigate why developing country suppliers are adopting socially sustainable practices and how the implementation process is both impeded and enabled.

Design/methodology/approach: A multi-case study approach is adopted based on four Ready Made Garment (RMG) industry suppliers in Bangladesh and the Bangladeshi buying houses of two large UK retailers. The primary mode of data collection is exploratory face-to-face interviews with 14 senior representatives. Findings are later interpreted using the Transaction Cost Economics (TCE) theory lens.
\end{abstract}

Findings: One factor motivating implementation is labour retention - a skilled labour shortage means employees will migrate to other factories if suppliers do not improve certain social standards. Barriers to implementation include a misalignment between the requirements of Western codes of conduct and the cultural and socio-economic context in Bangladesh. Enablers include a shift from auditing and monitoring to more open dialogue and trust between buyers and suppliers. We also reveal evidence of mock compliance, e.g. suppliers keeping two sets of timesheets, and of the complexities of social sustainability. For example, while some initiatives are unanimously positive, removing child labour from RMG industry suppliers has simply diverted it to other, less regulated and more hazardous industries like construction.

Research implications: An early, exploratory contribution is provided. The work could be extended, e.g. to other stakeholders like third-party auditors and Non-Governmental Organisations (NGOs).

Practical implications: Being aware of the motivations, barriers and enablers will help MultiNational Corporations (MNCs) promote good practice and anticipate the challenges they are likely to face in improving the social sustainability of their supply chains. Use of TCE leads to suggesting MNCs need to move beyond immediate suppliers and incorporate tier-two suppliers in their implementation efforts.

Social implications: Social sustainability improvements should benefit vulnerable workers, help suppliers develop longer term relationships with MNCs, and contribute to economic growth.

Originality/value: Most prior studies have been in the context of developed countries and focused on the perspective of the buying firm only.

Keywords: Social Sustainability; Developing Country Suppliers; Ready Made Garments Industry; Bangladesh; Exploratory Case Study; Transaction Cost Economics.

Article Classification: Research Paper 


\section{Introduction}

Multi-National Corporations (MNCs) face intense scrutiny on the sustainability of their economic, social and environmental performance. Interested parties range from employees, customers and trade associations to government agencies and Non-Governmental Organisations (NGOs) (Vachon and Klassen, 2006, Meehan and Bryde, 2011, Yakovleva et al., 2011). This scrutiny applies not only to their own performance, but to that of their upstream supply chain partners (Vachon and Klassen, 2006, Seuring and Müller, 2008b, Walker and Jones, 2012). For example, companies like Nike, Disney, Benetton and Adidas have been held responsible for the behaviour of their suppliers, e.g. when they harm the environment (Preuss, 2001) or violate labour laws (Graafland, 2002). As a result, environmental and social sustainability considerations are now fundamental to the purchasing and sourcing decisions made in MNCs (Carter and Rogers, 2008, Vachon and Klassen, 2008, Pagell and $\mathrm{Wu}, 2009)$.

This paper presents an exploratory study of social sustainability - which is concerned with the human side of sustainability, including human rights (e.g. child labour and freedom of association), health \& safety (e.g. safe working conditions and training), and community (e.g. charitable, philanthropic initiatives) - in the Ready Made Garments (RMG) industry of Bangladesh based on 4 Bangladeshi suppliers and the Bangladeshi buying houses of 2 major MNCs with headquarters in the UK. It is a timely study, given recent events in this sector in Bangladesh. On the $24^{\text {th }}$ of April 2013, the Rana Plaza building that housed five Bangladeshi apparel factories making clothes for Western brands such as Primark and Benetton collapsed, killing 1,129 people (BBC, 2013a, Guardian, 2013, Huffington Post, 2013). This was by far the deadliest disaster in the history of the apparel industry and followed shortly after two fires in November 2012 and January 2013 that killed 112 workers and 7 workers, respectively in Bangladeshi factories supplying Wal-Mart and SEARS (Bloomberg, 2012) and Inditex, the world's largest clothing retailer (New York Times, 2013).

Although there is a considerable literature on the environmental aspect of sustainability, work on the social aspect of sustainability lags behind (Carter and Rogers, 2008, Seuring and Müller, 2008a, Pullman and Dillard, 2010, Reuter et al., 2010, Sarkis et al., 2010). Social sustainability has only recently joined the mainstream management literature, driven by enhanced sensitivity in the developed world to ethical issues (Harrison and Freeman, 1999, Quazi and O'brien, 2000) and the business case for social reform: improvements in social sustainability have been linked to an increase in competitiveness (Porter and Kramer, 2006, 2011). Yet many MNCs are struggling with the management of social sustainability issues in 
their supply chains (Klassen and Vereecke, 2012) and successfully implementing improved conditions in upstream suppliers is a key contemporary challenge (Matos and Hall, 2007).

The Operations and Supply Chain Management literature on social sustainability is extremely limited (Daugherty, 2011, Gimenez and Tachizawa, 2012). Most studies to date have been conducted in the context of developed countries (Luken, 2006, Hussain et al., 2012) despite the obvious relevance to developing countries, where the impact of businesses on the poor has been mixed (Dobers and Halme, 2009, Werner, 2009). Many contributions have also focused exclusively on the perspective of the buying firm; the supplier's viewpoint requires further attention. It therefore follows that there is a need to conduct further research into social sustainability, particularly in the context of developing country suppliers to MNCs, as called for by Ehrgott et al. (2011) and Gimenez and Tachizawa (2012). Studying developing country suppliers is particularly important as they often find it difficult to incorporate Western style social standards in their factories, e.g. due to cultural differences (Hofstede and Hofstede, 2005, Gugler and Shi, 2009).

This exploratory study seeks to identify: (a) the reasons why developing country suppliers are adopting socially sustainable practices; and, (b) how the implementation process is both facilitated and impeded. In doing so, it makes three novel contributions to the field. First, it focuses on social sustainability, which is an under-researched area in general. Second, it provides an insight into the realities of implementing social sustainability in a developing country and in the context of a particularly labour intensive industry. And third, it provides not only the Western buyers' perspective but also the developing country suppliers' perspective, which is often neglected in the literature.

The remainder of this paper is organised as follows. A brief literature review is provided in Section 2 before the research method is outlined in Section 3. Findings are presented in sections 4-6 and relate to the: (i) key factors motivating implementation; (ii) social sustainability implementation process in which a number of barriers to implementation are highlighted; and, (iii) enablers or facilitators of successful implementation. In Section 7, we use Transaction Cost Economics (TCE) theory as a lens to interpret our findings - organised around three propositions on TCE from Grover and Malhotra (2003) - before the paper concludes with Section 8.

\section{Literature Review}

An overview of key social sustainability literature is provided in Section 2.1 below, which includes research on social sustainability in relation to buyers and suppliers and in the context 
of developed and developing countries. Section 2.2 then presents a discussion on theory used in prior work and, in particular, on the theoretical underpinnings of Transaction Cost Economics (TCE) - the theoretical lens we later adopt to explain findings from our exploratory study. Finally, an assessment of the literature follows in Section 2.3, where the main research gaps are identified and our research questions are formulated.

\subsection{Operations and Supply Chain Management Literature on Social Sustainability}

While many definitions of sustainability in general exist, one central concept is Elkington's (1998) Triple Bottom Line (TBL), which combines environmental, social, and economic performance. Hence, social sustainability is a component of the TBL (Kleindorfer et al., 2005) and deals with the management of human and societal capital (Sarkis et al., 2010). It pertains to forming and preserving fair management practices towards labour, communities and regions in the supply chain (Sloan, 2010). Here, we suggest social sustainability is a holistic concept that: (i) must consider the other TBL components, i.e. it is not implemented in isolation and must be integrated with economic and environmental performance considerations; (ii) recognises stakeholders within and beyond the supply chain; and, (iii) attempts to ensure long-term benefit for society. There are various tools for implementing social sustainability, ranging from a firm's own socially responsible practices or code of conduct, to third-party standards and supplier development programmes.

The Operations Management literature on social sustainability has included: links with logistics \& purchasing activities (Carter et al., 2000a, Carter et al., 2000b, Carter and Jennings, 2002b, a); sustainable supply chain governance models (Vurro et al., 2009); and, comparative studies on how broad Corporate Social Responsibility (CSR) policies, which include social sustainability, have been adapted by leading firms in different regions (Welford, 2004, 2005, Welford and Frost, 2006). Research has also investigated the use of social sustainability-based policies and practices in specific industries, particularly labour intensive industries like food (e.g. Manning et al., 2006, Spence and Bourlakis, 2009, Pullman and Dillard, 2010) and apparel (e.g. Tencati et al., 2008, Yu, 2008, Burchielli et al., 2009, Svensson, 2009, Illge and Preuss, 2012).

Much of the available literature is in the context of developed rather than developing countries and has focused on the buying firm only, as will be evident from the discussion below. As a result, most models of social sustainability are based on Western experiences (Fox, 2004) and do not consider the cultural, market and technological environments of developing countries (Quazi and O'brien, 2000, Belal and Momin, 2009, Hossain and Rowe, 
2011). Moreover, there is only limited understanding of how MNCs should construct or diffuse socially sustainable practices across suppliers (Carter and Rogers, 2008, Castka and Balzarova, 2008). It is therefore unsurprising that embedding MNC codes of conduct and third-party certifications in developing country suppliers is extremely challenging (Gugler and Shi, 2009). There is a clear need to understand what motivates suppliers to implement socially sustainable practices and how implementation is both impeded and facilitated. The first two of the following subsections review what is already known about this process from the existing literature in developed and developing countries considering the perspective of buyers and suppliers, where possible.

\subsubsection{Research on Social Sustainability in Buyers \& Suppliers: Developed Countries}

Research in developed countries includes Burchielli et al. (2009), Awaysheh and Klassen (2010), Elg and Hultman (2011) and Walker and Jones (2012). But none of these papers incorporated the perspective of suppliers to the focal buying firm. First, Burchielli et al. (2009) conducted a case study of the Australian FairWear Campaign (FWC), identifying how appropriate regulations can create ethical supply networks. Second, Awaysheh and Klassen (2010) conducted a survey of Canadian managers in three industries, finding greater physical distance from the buyer and a lack of law enforcement lead to lower social sustainability implementation in suppliers, and that better supply chain transparency can help mitigate these problems. Third, Elg and Hultman (2011) surveyed Swedish retailers and compared them with best practice in Sweden in the form of Ikea's sustainability programme. Most recently, Walker and Jones (2012) identified the internal and external barriers and enablers to the TBL through a literature review and case studies of 7 leading UK companies. Enablers included: customer/stakeholder pressures; a desire to minimise reputational risk; the need to align purchasing and corporate strategies; collaboration with suppliers; top management commitment; competitive advantages gained from being sustainable; and, inter-departmental cooperation. Meanwhile, barriers included: limited resources; low prices offered by buyers; lack of management and supplier commitment; and, communication problems \& cultural mismatch with suppliers in different locations. While the authors provided a valuable contribution, they conceded that their work concentrated on large buying firms and that there was a need to research buyer-supplier dyads, thereby integrating the (typically smaller) supplier’s perspective.

Few papers have focused on the problems faced by suppliers in improving social standards (e.g. Jorgensen and Knudsen, 2006, Baden et al., 2009, Ciliberti et al., 2009). First, Jorgensen 
and Knudsen (2006) surveyed the Sustainable Supply Chain Management (SSCM) practices of 300 Danish Small and Medium sized Enterprises (SMEs), elaborating the concept of governance in global value chains. Second, Baden et al. (2009) found the attitude of UK SME owners/managers to be a key factor motivating social improvements. Finally, Ciliberti et al. (2009) studied SA8000 implementations - the global social accountability standard encouraging firms to develop and maintain socially acceptable workplace practices - by Italian SMEs, finding information asymmetry and transaction costs decrease when the most powerful supply chain partner implements the standard.

\subsubsection{Research on Social Sustainability in Buyers \& Suppliers: Developing Countries}

Beschorner and Müller (2007) highlighted the prominent role played by stakeholder pressure in motivating social sustainability in developing countries. Similarly, pressure from buyers who make socially sustainable practices an order qualifier was highlighted in Luken and Stares (2005). Other key developing country studies include those by Kortelainen (2008), Tencati et al. (2008), Lim and Phillips (2008), Yu (2008), and Lee and Kim (2009). Kortelainen (2008) used case studies in Chinese high-technology industries to evaluate whether auditing labour conditions is effective for improving social standards, concluding that it is beneficial but that auditors needed to update their skill set. Meanwhile, Tencati et al. (2008) focused on the impact of sustainable sourcing policies on 25 Vietnamese suppliers to EU and US MNCs. The authors concluded that although there is a business case for sustainability, practices tend to be imposed on suppliers in such a manner that they cannot be maintained in the long-run; and that a supportive approach is needed, based on collaboration and education.

Importantly, both Lim and Phillips (2008) and Yu (2008) focused on dyadic relationships between developed country MNCs and developing country suppliers in the footwear industry. First, Lim and Phillips (2008) presented a case study analysis on four of Nike's Korean and Taiwanese suppliers finding an arms-length approach to implementing codes of conduct to be ineffective. Instead, collaboration and offering compliant suppliers minimum order quantity incentives facilitated implementation. Second, Yu (2008) conducted an explanatory study on the implementation of Reebok's labour-related code of conduct at a major Chinese supplier. The author identified barriers to implementation, including: the buyer's intentions to reduce costs and not share in the expense of implementation; competition amongst suppliers; and, a lack of government enforcement of labour laws. Yu (2008) suggested two possible solutions: cost sharing and combining the regulatory power of voluntary codes with compulsory state 
legislation. Finally, Lee and Kim (2009) studied CSR in Korea's electronics industry, also finding legal requirements to be an important driver.

\subsection{Theory in the Social Sustainability Research Reviewed}

Relatively few researchers have used theory when studying social sustainability, as noted by Carter and Easton (2011) in the broader context of SSCM research. The few theories that have been used include: stakeholder theory (Belal, 2002, Pagell et al., 2010, Park-Poaps and Rees, 2010, Liu et al., 2011, Wu and Pagell, 2011); the Resource Based View (RBV) (Carter and Rogers, 2008, Pagell et al., 2010); Transaction Cost Economics (TCE) (Carter and Rogers, 2008, Jiang, 2009, Pagell et al., 2010); structuration theory (Pullman and Dillard, 2010); and, contingency theory (Walker and Jones, 2012). For example, Belal (2002) used stakeholder theory to consider the extent to which social audits meet stakeholder needs. The author made a distinction between stakeholder management, where a supplier does just enough to keep a customer loyal, and stakeholder accountability, where the supplier genuinely commits to the customer's values and feels a deeper social responsibility. Some authors have combined theories, including the aforementioned stakeholder theory. For example, Pagell et al. (2010) found that the RBV and TCE provide conflicting explanations for the evolving use of purchasing portfolios in SSCM, but that stakeholder theory can help to reconcile the two perspectives.

Other uses of theory include Walker and Jones (2012), who used contingency theory to develop a typology of approaches to SSCM and investigate factors influencing SSCM. A final example is Jiang (2009), who applied TCE to develop and justify a conceptual model that explains how governance relationships lead to supplier compliance with codes of conduct. The author tested the model using data from compliant and non-compliant suppliers, concluding that non-compliance is often caused by the buying firm, such as by conducting an audit and leaving a supplier with an unrealistic set of problems to resolve with no assistance. Although it was applied by Jiang (2009), Carter and Easton (2011) found that TCE is one of the lesser used theories in the study of sustainability in supply chain management and that this presents an opportunity for future research. Moreover, TCE has been identified as an effective tool for evaluating buyer-supplier relationships by Grover and Malhotra (2003). Similarly, our findings in sections 4, 5 \& 6 will also demonstrate that TCE is a useful lens for understanding the phenomenon of social sustainability implementation in developing country suppliers by developed country buyers. In the following section, we briefly outline TCE, its 
main constructs and three propositions that we will later return to after presenting our exploratory study (see Section 7).

\subsubsection{Transaction Cost Economics (TCE) Theory}

The initial TCE framework was proposed by Coase (1937) and further developed by Williamson (e.g. Williamson, 1971, 1975, 1985), who suggested that transaction costs consist of both the direct costs of managing relationships and the opportunity costs of making poor or inferior decisions. TCE makes two key assumptions about human behaviour (Williamson and Ghani, 2012): (i) bounded rationality (from Simon, 1957), i.e. that decision makers are limited by their cognitive, communication and information processing capabilities, which might lead to additional costs (Williamson, 1975, 1985); and, (ii) opportunism, which indicates that decision makers may, out of self-interest, behave dishonestly or violate agreements (Rindfleisch and Heide, 1997), meaning firms have to incur partner monitoring or asset safeguarding costs to tackle the problem.

Key constructs of TCE include: asset specificity, uncertainty, and governance mechanisms (Grover and Malhotra, 2003). Asset specificity refers to the transferability of assets supporting a transaction, and can be either human (e.g. training) or physical (e.g. equipment investment) specificity. Costs that have little or no value outside a certain exchange relationship are highly asset-specific investments. Uncertainty refers to unexpected changes in circumstance surrounding a transaction and can be either ex ante, i.e. environmental uncertainty (e.g. uncontrollable problems at the contract agreement stage) or ex post, i.e. behavioural uncertainty (e.g. performance evaluation problems). Finally, governance mechanisms refer to the processes and structures used to ensure the strategies and objectives of different parties are aligned (Oshri et al., 2011, pp 178). Governance may be either market or hierarchically oriented, although hybrid forms have also been suggested (e.g. Powell, 1990, Williamson, 2008). In market governance, the coordination of goods and services occurs through demand and supply forces. Under hierarchical (or vertical) governance, there is a dominant entity that controls and directs the flow of materials and services.

The analysis of our data in Section 7 is organised around three key propositions on TCE for the operations and supply chain management field by Grover and Malhotra (2003, pp. 460) and summarised in the following: "Bounded rationality and opportunism give rise to transaction costs. These costs are higher under conditions of high asset specificity and high uncertainty. The most efficient governance mechanism (markets or firm) needs to be chosen 
to organise economic activity. In general, lower transaction costs favour markets, while higher transaction costs favour hierarchies” (Grover and Malhotra, 2003).

\subsection{Assessment of the Literature}

To conclude, the following gaps can be identified from the literature:

- Most prior research has been conducted in the context of developed countries. Further research is required in developing countries, e.g. to understand the extent to which codes of conduct developed in the West apply to developing country suppliers with different cultural and socio-economic values; and, how they can be effectively implemented.

- Much research has focused exclusively on buyers, typically MNCs. Further research is required that captures both the buyer and supplier perspectives of social sustainability.

- Few prior studies have made use of theory. Further research is required in which theory is used, e.g. to interpret and improve understanding of empirical evidence.

In response, this exploratory paper investigates the implementation of socially sustainable practices in a developing country context - incorporating the views of suppliers and buyers to understand the ground realities of the process. Our findings are later interpreted using the Transaction Cost Economics theory lens, as introduced above. We begin with the following three research questions (RQs), which are also illustrated in Figure 1:

RQ1: Why are developing country suppliers adopting socially sustainable practices?

RQ2: How is the achievement of social sustainability impeded?

RQ3: How can the implementation of social sustainability be facilitated?

[Take in Figure 1]

\section{Research Method}

An exploratory case study of 4 Bangladeshi suppliers in the Ready Made Garments (RMG) industry has been undertaken, supplemented by the Bangladeshi buying houses of 2 major UK retailers. Section 3.1 describes the research context before Section 3.2 justifies the choice of method; finally, Section 3.3 outlines the data collection and analysis procedure.

\subsection{Research Context - Ready Made Garments (RMG) Industry in Bangladesh}

Social conditions in the labour intensive RMG industry have been the subject of much public scrutiny (Emmelhainz and Adams, 1999, De Brito et al., 2008, Maccarthy and Jayarathne, 2011). Bangladesh is one of the world's least developed countries with a high population 
density and high level of poverty; it is vulnerable to climate change and has inefficient institutional aspects (Huq and Ayers, 2008). Yet Bangladesh has shown tremendous growth in the RMG industry (McKinsey, 2011) with exports of \$19billion in 2012, second only to China (BBC, 2013b). The sector's economic performance has not, however, led to a proportionate increase in social performance. For example, Akhter et al. (2010) reported poor hygiene standards, a shortage of drinking water and recreational facilities, and the sexual harassment of women, who make up the majority of RMG industry employees. And, alarmingly, in a span of just two years, there has been a series of deadly incidents resulting from failures to improve social conditions, including factory collapses and fires. Not surprisingly, much global attention is now focused on the need to improve social standards in the RMG sector of Bangladesh. The RMG industry in Bangladesh therefore provides a rich and appropriate setting for exploring our research questions.

\subsection{Multiple Case Study Approach}

The infancy of social sustainability research calls for an exploratory study (Saunders et al., 2009). Conducting exploratory research through the case study method is appropriate when a phenomena is at the developmental stage and its variables have not been properly identified (Voss, 2008). Case studies allow for a thorough analysis of a phenomenon in a real-life situation and can provide in-depth insight (Eisenhardt, 1989, Yin, 2009). They enable the elicitation of rich data through a variety of techniques, including interviews, observations and document analysis, allowing for cross-validation (Yin, 2009).

The majority of case study sustainability research is based on a single case and stage of the supply chain (Seuring, 2008, Carter and Easton, 2011). But multi-case research can be appropriate when exploring new areas; it can augment external validity, guard against observer bias (Handfield and Melnyk, 1998; Voss, 2008; Barratt et al. 2011), aid triangulation, and - to a degree - improve generality (Voss 2008; Yin, 2009). It can help create more robust and testable theories than those based on single cases (Eisenhardt, 1989, Meredith, 1993, Yin, 2009). We adopt a multi-case study approach based on four Bangladeshi RMG industry suppliers, where each is a case. This core set of cases is supplemented by evidence from the Bangladeshi buying houses of two major UK apparel retailers with annual sales in excess of £9bn and £3bn in 2011. The retailers buy from two of the suppliers, thereby aiding triangulation. All of the companies involved in the study meet the following criteria: (i) they are involved in the RMG industry; (ii) they have a physical 
presence in Bangladesh, i.e. a factory or buying house; and (iii) they supply international customers or are international customers that buy goods from Bangladesh.

\subsection{Data Collection and Analysis}

The firms chosen for this study met the criteria above, but they were also chosen because we were confident of gaining good access to rich data. The primary mode of data collection has been interviews; other methods employed included factory tours and secondary data collection, e.g. from audit reports. In total, 14 semi-structured face-to-face interviews have been conducted with owners and managers dealing with supply chain and human resource/social compliance issues across the four suppliers and two buyers. All interviews were recorded and transcribed. Interviewees were identified either through personal contacts or via referrals from a previous interviewee, ensuring participants were both accessible and cooperative (Bryman and Bell, 2007, Malhotra and Birks, 2007). Personal contacts helped to gain trust and enable 'frank and open' discussions - as will be demonstrated by our rich and candid data - which would otherwise have been difficult given the sensitive nature of the topic. By the end of the fourteenth interview, the value added per interview was minimal and we were arguably approaching saturation. All of the interviews and factory tours were undertaken by one of the authors of this paper, who is a native of Bangladesh.

The four suppliers are hereafter referred to as suppliers A to D and the two buyers as Buyer 1 and Buyer 2. An overview of the companies and interviewees is provided in Table I, which also indicates example buyers/suppliers. For example, Buyer 1 and Buyer 2 are customers of Supplier C, while Buyer 2 is a customer of Supplier D. Some customers, including buyers 1 and 2, have their own code of conduct that suppliers must adhere to; others simply expect suppliers to be accredited by an international third-party, like Worldwide Responsible Accredited Production (WRAP) or the Supplier Ethical Data Exchange (SEDEX).

\section{[Take in Table I]}

Multiple steps have been taken to ensure reliability and validity (Bryman and Bell, 2007, Yin, 2009). The interviews were conducted in two rounds, which improved the focus of the research, allowed for follow-up questions, and helped identify possible future research areas (Van Teijlingen and Hundley, 2001, Bryman and Bell, 2007). Transcripts from each case were analysed individually before cross-case analysis of suppliers, buyers and dyads was undertaken to identify common themes (Creswell, 2009, Barratt et al., 2011); tables were 
constructed to support the process of searching for patterns in the data (Hartley, 2004). Finally, it is important to be aware of potential biases when analysing case study data. Most prominently, there was the potential that interviewees from suppliers in particular would exaggerate their degree of social sustainability to put their company in a positive light. This was considered while interpreting the data and drawing conclusions. But, in general, this did not appear to be a problem - the interviewees were generally extremely open about their shortcomings.

Next, we outline the study's findings, identifying factors motivating social sustainability, and the barriers and enablers to implementation in sections 4, 5 and 6, respectively.

\section{Why are Socially Sustainable Practices being Adopted? (RQ1)}

The key motivators, barriers and enablers of social sustainability implementation for each case are presented in Table II. The table also indicates whether a factor has previously been identified in the literature or is, to the best of our knowledge, presented here for the first time. The following four subsections summarise the key factors motivating social sustainability implementation in the four suppliers; barriers and enablers will be discussed in sections 5 and 6.

[Take in Table II]

\subsection{External Stakeholder Pressure}

A wide range of stakeholders are present in the RMG industry, including buyers, media, consumers, trade associations, NGOs and the government; and external stakeholders are a key motivational factor for all four suppliers. The first four stakeholders in particular have been major driving forces. Most prominently, buyers impose pressure by making certain social standards mandatory for a supplier to be considered for a contract. In 2005, the MultiFibre Agreement (MFA) - a quota system established by the 1974 General Agreement on Tariffs and Trade (GATT) - expired. This system had meant orders were proportionately distributed across regions and factories. But since 2005, buyers have been free to choose which suppliers they use, enabling them to exert greater coercive pressure over the practices suppliers employ. Supplier D’s Managing Director, for example, now described social compliance as being a "matter of survival". Some of the suppliers are prospering in this free market, e.g. Supplier B has attracted important retailers like H\&M. In contrast, Supplier A recently failed to win an order from Tesco due to its lack of compliance with their code of conduct. 
The pressure exerted by buyers to tighten up standards across the supply chain has been influenced by other stakeholders - like the media and consumer expectations, e.g. in Europe and the US. Supplier B's Deputy Managing Director explained that "the eyes of the world are on Bangladesh's garments sector ... we [Bangladesh] are exporting more than $\$ 20$ billion worth of garments per year. We are pressurised by buyers [to improve] and they are pressured by the media [who influence public/customer perceptions]". To facilitate improved standards, some buyers actively train suppliers. For example, Supplier B's Human Resource (HR) Manager had attended programmes run by MNCs like SEARS, K-Mart and H\&M, where buyers introduce their company's code of conduct, provide guidance on how to adhere, and inform suppliers of recent changes to a code.

In addition, the Bangladesh Garment Manufacturers and Exporters Association (BGMEA) - a trade body representing woven, knit and sweater garment manufacturers and exporters plays a mediating role in supplier development. The BGMEA inspects suppliers to ensure, for example, that children are not employed. Where necessary, fines are imposed and, in extreme cases, suppliers lose their BGMEA membership status, affecting their credibility and order winning capabilities. Like some buyers, the BGMEA and other similar associations also run supplier workshops.

In contrast, lesser roles are currently played by NGOs and the government. Most suppliers could not attribute any benefits to the work of NGOs; one even commented that some NGOs are corrupt - threatening to incite workforce unrest unless they were paid bribes. But this contradicts both buyers who felt that NGOs play an important role in training and raising awareness. Meanwhile, the general consensus across suppliers and buyers was that the government does not play a large enough role, and that there is again a problem with corruption. This, it was argued, is most prominent in the government's labour agency which checks suppliers comply with labour laws yet, it was claimed, regularly takes bribes to ignore violations. We will return to the problem of corruption when we discuss the implementation process in Section 5.

\subsection{Owner Characteristics}

Owner attitudes in the supplying factories play a role and are shaped by their experience, education and professional background. All but one of the owners and directors interviewed had received overseas education, and some had prior work experience in a MNC. Most felt that complying with social standards was now a minimum requirement and agreed with their customers that workers' rights and comforts should be respected. Supplier D, for example, 
goes beyond compliance by having aisle widths between rows of machinists double the legal requirements. It was claimed that this is because of the owner's positive attitude. Many owners also exerted philanthropic characteristics, e.g. providing financial aid to employees with sick relatives and sponsoring the education of employees' high-achieving children. Supplier A's owner even gave employees a month's wages to aid recovery after a fire destroyed many of their homes.

\subsection{Competition amongst Suppliers, including for Skilled Labour}

Competition amongst suppliers also motivates improvements. There is of course competition for orders, heightened by the free market described above. But there is also competition for labour, as highlighted in the cases of suppliers B and D. High global demand for garments from developing countries like Bangladesh have led to an increase in the number of factories; this, in turn, has led to a significant RMG industry labour shortage. Therefore, employees have greater power and factories must improve their standards or risk losing their best workers to other factories offering better conditions. For example, Supplier B's Managing Director stated that: "As an industry, we have a tremendous shortage of workers ... If we are not socially compliant, the workers won't come to our factory ... Competition to get workers amongst the factories is forcing us to be compliant". Hence, in addition to top-down drivers, there is also a bottom-up push for social sustainability improvements that are valued by employees.

\subsection{Economic Benefits of Social Sustainability}

The above suggests improvements are influenced by factors like goodwill and the need to compete for qualified labour. While this is true, social sustainability is also increasingly viewed as having a positive impact on productivity - hence, improvements can be good for business. In fact, there is evidence from all four suppliers and both buyers that social sustainability can lead to economic benefits. Suppliers are increasingly aware, for example, that low social standards lead to higher sickness rates and worker absences, which reduce output. Indeed, Supplier A recently paid for Hepatitis C (HCV) tests for its workforce because such diseases are common in Bangladesh. The Managing Director explained that: "You may be surprised that from around 700 workers, 28 actually had this disease." These initiatives also contribute to worker retention, which cuts training costs as well as being good for productivity. Meanwhile, it was argued by Buyer 1's Compliance Executive that being socially sustainable helps attract bigger customers and secure more lucrative contracts. 
Not all RMG industry suppliers in Bangladesh are convinced that social sustainability makes economic sense. The owners of our four suppliers suggested that some other factories do not wish to go beyond compliance and view implementation as a cost, not an investment. These owners were now causing friction between factories. For example, Supplier B had received a request from a neighbouring factory to stop providing transport for employees to and from the factory as workers in the neighbouring factory were now demanding the same service. Presumably, the owner did not want this extra expense but feared losing their staff as a consequence (see Section 4.3 above).

\section{Implementing Social Sustainability: The Good, the Bad and the Ugly (RQ2)}

Section 4 summarised key factors motivating improved social standards in RMG industry suppliers in Bangladesh, where a key pressure was from buyers. The key components of a code of conduct (or third-party certification) used by buyers to diffuse social sustainability into their supply chain relate to: employee wages \& benefits, child \& forced labour, workplace harassment, and working hours \& conditions. When auditing suppliers, buyers typically have two main criteria: technical and social compliance. If the supplier passes the preliminary technical audit, a social audit team completes an in-depth assessment. Social audits typically involve reviewing the manufacturer's labour standards (e.g. documents regarding labour contracts, working hours and company policies) and inspecting working conditions, including health and safety issues. In addition, following the recent Rana Plaza disaster, some buyers like Tesco and Benetton have promised to conduct surveys to examine the structural integrity of buildings, even though this is normally the responsibility of government inspectors (Telegraph, 2013, Huffington Post, 2013). Audits are often prearranged, but checks on existing suppliers can occur randomly or be completely unannounced; and auditors may question employees privately. If only a minor violation is found, a supplier may be given a 1-year approval, followed by another audit. If a major violation is found, a buyer may withhold orders and give the supplier 3-6 months to rectify conditions. Typically, a supplier will only fail altogether if there is a serious violation, e.g. child labour. Audits may be conducted by the buyer directly or by a third-party auditor.

Against this backdrop, the remainder of this section presents an insight into the barriers to implementing social sustainability, before Section 6 focuses on how implementation can be enabled.

5.1 The Good - Positive Outcomes from Becoming Socially Sustainable 
Buyers' codes of conduct are displayed in the local language - Bangla - on the shop floors of suppliers A, B and D together with contact details for a representative from each buyer. Employees can therefore contact a buyer directly if they have a grievance. In Supplier B, for example, employees also have free access to a doctor and to proper safety equipment, which was not the case prior to the codes being implemented. All the suppliers must also educate employees on their rights and provide them with a handbook. Auditors check these measures are in place, e.g. by questioning employees to assess how well they understand their rights, such as to a pay slip, sick leave, maternity leave, etc. These measures mean employees are more aware of what to expect, making them less vulnerable to exploitation. Supplier A's HR Manager admitted that: "Five years ago, our workers didn't even know what their basic salary or overtime rate was, but now the situation has changed drastically". This has improved working standards for some of the most vulnerable groups of society, including low skilled, low paid (mostly female) employees. Child labour in the RMG industry has also reduced; for example, all four suppliers claimed to have removed child labour altogether.

Implementing the above improvements is initially costly, but there is evidence that this has indeed led to increased productivity. Hence, there are benefits for employees and organisations. Supplier D’s HR Manager explained that the company owns two factories one which has improved its standards and one which lags behind. He claimed that, with the same number of machines, the compliant factory is, on average, more productive than the non-compliant factory; and, that staff retention rates are higher. Compliant factories can also secure longer term orders from buyers, while Supplier D’s Managing Director suggested compliance has increased the firm's bargaining power. He argued that: “We are in a stronger position to negotiate with buyers compared to a non-compliant factory which is on 'the back foot' from the very beginning." He also stated that "buyers feel more secure that a compliant factory has a minimum level of performance and quality." This was supported by the buying firms; for example, the Country Head of Buyer 1 explained how pioneering or earlycompliant factories have gained some first-mover advantages, strengthening their market position.

\subsection{The Bad - Negative Aspects of the Social Sustainability Implementation Process}

Implementing social sustainability is not all positive and here we pick out three examples of negative aspects of the process. First, the primary complaint in all four suppliers was that, although buyers want factories to improve standards, they will not share the costs of implementation and are continuing to drive down prices. For example, Supplier B's Deputy 
Managing Director pointed out: “It is a buyer's market ... buyers are taking advantage of price wars between supplier factories. But if they buy cheap from Bangladesh, then the benefits to the workers and society will also be cheap." He claimed that by failing to share costs or increase prices, buyers were not considering the long term viability of the suppliers or how improved standards could be maintained. Yet Buyer 1's Supply Chain Manager felt that the prices they were paying were fair and could lead to improvements in social sustainability that also allowed suppliers to be economically sustainable. He questioned: "If they are not making a profit, then how are they running their factories?" Benefits in terms of greater bargaining power were earlier reported for Supplier D, but even this supplier complained about having to bear the costs of implementing social sustainability.

Second, it was claimed that standards vary and are inconsistent. This includes across codes of conduct, where a particular supplier has to satisfy the standards of multiple buyers. But it also includes the inconsistent application of a particular standard during the auditing process. Third-party auditors were thought to have higher expectations than the buyers themselves; hence, a supplier's rating may greatly depend on who conducts the audit. Third-party auditors were also viewed as being less understanding, e.g. of the difficulties of achieving compliance. Meanwhile, Supplier C's HR Manager suggested that a third-party auditor may submit an unfavourable report so they can return in 3 months' time to re-audit the supplier and receive another fee. It was also claimed some third-party auditors go to extreme lengths to detect code breaches to secure a second visit; and fraught relationships between suppliers and thirdparty auditors are evident in several cases. For example, Supplier B's Deputy Managing Director explained: "A few years ago, I had an auditor [third-party auditor] whose aim was to prove I was using excess overtime. But he could not find any proof ... eventually he took out my generator log book and saw that the generator was on at 8pm, which means my factory was still running when it shouldn't have been. On that basis, he failed the factory."

Third, while social sustainability implementation has reduced child labour in Bangladesh’s RMG industry - which, in isolation, is extremely positive - it has diverted children to other, less regulated and often more dangerous industries like construction. For example, Supplier B’s Managing Director stated that: "By banning child labour from our industry, which is the most regulated in the country; we have actually shifted these children to more dangerous professions such as construction, which is not properly monitored." This highlights the complexities of improving social sustainability in one particular industry when it is faced with tackling wider socio-economic problems. 


\subsection{The Ugly - Mock Compliance and Corruption}

Much of the case study evidence points to mock compliance, where a supplier appears to be complying with a code of conduct but is in fact concealing non-compliance. All of the suppliers and buyers admitted to some form of mock compliance or were aware that some suppliers practiced mock compliance to pass audits. For example, some buyers require suppliers to close on Fridays - a public holiday in Bangladesh. Local law also states that employees should have at least one day’s leave per week, e.g. Fridays. Many factories open on Fridays nonetheless but conceal this from buyers and auditors. Similarly, the International Labour Organisation (ILO) convention states that employees should not work more than eight hours per day, while local law limits overtime to two hours per day. However, again, working hour violations are common to meet output targets. While, at first glance, these practices may appear to exploit the workforce, overtime is actually welcomed by many employees as the hourly rate is higher and provides an important income supplement. In fact, Supplier C's HR Manager was aware that employees often slow down towards the end of the week to ensure overtime is needed; and, if a company does not offer overtime, it risks losing its workforce to another factory. Hence, while some social reforms like sick pay are driven through by employees, others are held back. Supplier B’s Deputy Managing Director explained that: “Buyer XYZ [a major multinational retailer] only allows 8-hour shifts with 2 hours overtime per day. But it is not possible to conform to this standard in the peak season and workers want more overtime as they get double the basic rate. If we only gave the workers 48 hours of overtime per month, they would leave and go elsewhere."

The above results in suppliers developing 'work-arounds' that allow them to mock comply with certain standards that are not amenable to the workforce. For example, Supplier D's HR Manager referred to the "charade" whereby his factory holds a gold WRAP certificate - the highest possible rating for an initial audit - and has zero violations according to its SEDEX rating, yet frequently flaunts working hour regulations. Suppliers are beating the system in various ways, including - according to the HR managers of suppliers B and D - by maintaining two timesheets: one shown to buyers/auditors, which complies with regulations; and one used to pay workers, which reflects actual practice. It was claimed in suppliers B and D that not only do employees participate - knowing it is in their interests if they want to retain overtime - but that auditors and buyers are also sometimes aware of the charade. For example, Supplier B’s Deputy Managing Director stated that: “Some customers understand the issue with overtime and do not ask to see how much overtime workers have done, or they will just check that workers have been paid fairly for their hours and were not forced to work. 
If, at the end of the year, they think you have done too much overtime, they will ask you to cut back but they won't fail the factory ... But Buyer XYZ's audits are carried out by third-party auditors who are not very understanding of this dilemma. So, we have to maintain two sets of records. The buyer and auditors are well aware of this but they turn a blind eye [as long it is hidden from them].” There appears to be inertia on changes to overtime practices from all sides, as it would, for example, increase costs for both buyers and suppliers. Other mock compliance examples related to healthcare, and were presumably less supported by the workforce. Local law states that a full-time doctor and nurse should be employed in a factory with >350 employees. Yet the HR Director and Compliance Manager of Supplier A admitted that medical staffs are only present on an audit day.

Some suppliers claimed that their buyers were not genuinely serious about social sustainability and were only interested in improving their reputation and avoiding bad publicity. It was also argued that if MNCs took greater interest in their tier two or three suppliers, then they would uncover more alarming social problems in their supply chains. One example from Supplier B's Deputy Managing Director involved the use of Uzbekistan cotton, which was banned in the US and EU following widespread reports that children and convicts were used to pick the cotton. Yet he believes that about $40 \%$ of cotton used in Bangladesh’s RMG industry comes from Uzbekistan. He signs an agreement each year to confirm Uzbek cotton is not used but suspects his cotton supplier, which sources its cotton from a range of countries, buys from Uzbekistan, and that buyers are also aware that this is likely. Once cotton has been spun into thread, it is impossible to detect its origins. Both the examples on timesheets and Uzbek cotton imply that some buyers may ignore noncompliance providing it is not visible or cannot be traced to them, meaning they can deny knowledge of its existence if confronted.

All four suppliers found it difficult to fully adhere to codes of conduct based on the cultural and socio-economic conditions of developed countries. This included the idea of a nursery or childcare centre in the place of work. This is largely unheard of in Bangladesh infants are typically cared for by another relative when their guardian is at work - but is stipulated as a requirement in buyer codes of conduct. Hence, suppliers must bear the cost, but the facility itself is only used when auditors are expected. This highlights the lack of alignment between the codes of conduct and the local context, which leads to further mock compliance. Supplier C's HR Manager explained that: "We have this facility and incur the cost just because buyers do not understand the reality of our country. This is a total waste of 
money.” In fact, Buyer 2's Head of Compliance was aware of this and acknowledged "some suppliers create a day care centre just for the sake of compliance”.

Finally, part of the reason why suppliers can circumvent aspects of codes of conduct is that corruption is rife, including, it was alleged, involving government officials. Supplier A's Compliance Manager was scathing in his comments: “The government labour agency comes to audit every 6 months, but mainly they come for money. They will see the violations, but if you bribe them they will go away and just ask you not to do it in the future." This lack of law enforcement is a major barrier to driving through social reform and was acknowledged by all four suppliers and by Buyer 2.

\subsection{Summary of Barriers to Social Sustainability}

From sections 5.2 and 5.3, it follows that the barriers to social sustainability in Bangladesh's RMG industry include: pressure to reduce prices and buyer reluctance to share implementation costs; fraught relationships between actors, most prominently between suppliers and third-party auditors; suppliers covering up non-compliance (mock compliance); buyers ignoring violations, thereby failing to drive through genuine improvements; misalignment between codes of conduct and local culture; and, a lack of government support or law enforcement. Building on this, Section 6 explores how the barriers to social sustainability could be, and are being, overcome.

\section{Enablers of Social Sustainability (RQ3)}

A primary enabler of social sustainability identified by three suppliers and Buyer 2 was higher prices and larger orders for compliant factories to incentivise improvements. For example, with higher prices, the suppliers argued they would be able to give back more to society. But while Buyer 1's Supply Chain Manager agreed that larger orders could enable improvements, he argued that social sustainability must be evaluated alongside many other factors when awarding contracts - not only environmental sustainability, but factors like capacity availability and delivery performance: "We must award orders according to capacity. And even if a supplier performs well in terms of compliance, we have to be sure that they can deliver."

One difficulty with social sustainability is that different buyers have different codes of conduct. It is therefore unsurprising that two suppliers suggested establishing a single RMG industry code of conduct. This would increase clarity over what a supplier should achieve, may lead to more consistent auditing, and make it easier for suppliers to win contracts from 
new buyers as there may not be the need for a new audit. Beyond industry-level uniformity, three suppliers argued that codes of conduct should reflect broader cultural and socioeconomic conditions. For example, Supplier C’s HR Manager stressed that buyers “need to do a root cause analysis of why labour laws are violated in Bangladesh." Returning to the problem of child labour being diverted to other industries (from Section 5.2), Supplier B's Managing Director explained that: "the garments industry is the most regulated industry in the country; we are shifting child labour to more dangerous professions, such as construction, which are not monitored and where workers do not get proper or timely wages". It was suggested that a solution more considerate of the local context would be to introduce age brackets for employees linked to the level of stress and potential hazard they are exposed to, allowing children to earn an income in the RMG industry but in a safe way while also receiving an education from the supplier. Similarly, it was suggested that codes of conduct should not stipulate a nursery be available if local culture means employees would not use this service.

More generally, it was felt that there needs to be a shift from the auditing and monitoring of suppliers towards supplier development. Indeed, Buyer 2's Head of Compliance predicted that, in the future, "buyers will shift from auditing to supplier development" while Supplier C's HR Manager acknowledged that buyers are beginning to change their approach from “policing duties" to "factory development”. Similarly, another enabler was support from buyers for education and training. It was also suggested that a culture of trust and openness should be fostered, whereby a supplier can go to a buyer when they are having difficulties with a particular improvement to obtain advice without feeling this will impact future orders. In fact, Buyer 2's Head of Compliance suggested that he would like to work with suppliers to solve their problems. For example, he realises that working-hour violations are common and cannot be stopped immediately but that, by working together, compliance could gradually be achieved. He explained: "If suppliers are forced to hide, buyers can't help them rectify the process ... we encourage suppliers to show us the original timesheets, even if they are violating labour laws because then we can help them to address the issues.” Buyer 2's open approach was appreciated by the factory compliance managers of suppliers C and D, both of which supply directly to Buyer 2. According to Supplier C’s Compliance Manager, “the requirement of [Buyer 2] is that you have to show the original documents, even if you are violating the labour law." But he also added: "It is only recently that they have begun to understand the practical realities.” 
But while openness would be beneficial to bringing about gradual change, suppliers and buyers appear to accept that on audit day, when future orders are potentially at stake, the atmosphere changes and can be rather tense and adversarial - suppliers often revert to hiding violations, meaning auditors may revert to trying to find the faults they are hiding. Buyer 2's Head of Compliance explained that: "We try to work together with suppliers to solve problems. But on audit day, this does not always happen. For example, a factory tried to hide working hour violations during an audit and got a poor rating, which hampered its orders. But then when I called the supplier to the office for a meeting where the negative environment of the audit was not there ... he came with all his original records and I was able to show him where he made the mistake and how to rectify it."

Education and training, as suggested above, can be important not only for suppliers but for employees in the local offices of buyers as well, as noted by Buyer 1. While the headquarters of MNCs may be far removed from the local context in Bangladesh, their employees in Bangladesh will share many of the same cultural values and experience the same socioeconomic conditions as the suppliers. Buyer 1's Supply Chain Manager explained that its "[local] compliance team goes to the UK head office or the India regional office for training ... sometimes people also come from abroad to train them. We are also sent guidelines on what we should follow and what our suppliers should follow, with examples of best practice."

The final enabler of social sustainability is law enforcement. Supplier B is the only supplier in our study located in the tightly regulated and enforced Export Processing Zone (EPZ) - an area where compliance must be high but, in return, duties are lower and customs intervene less, making import/export more straightforward - and has greater adherence to social standards than suppliers outside the zone. If labour laws, for example, were more readily enforced in factories outside the EPZ then these suppliers would have to improve their social standards. Given that around 80\% of the country's exports are from the RMG industry, there must surely be an incentive to ensuring the sector meets the expectations of global markets so the economy can continue to benefit from garment manufacture.

\section{Discussion: Social Sustainability using the Transaction Cost Economics (TCE) Lens}

This paper has included the 'ugly' side of social sustainability implementation, including, for example, evidence of mock compliance by suppliers, such as hiding violations, and unethical behaviour by buyers, such as turning a 'blind eye' to violations. These aspects can be interpreted as costs associated with buyer-supplier transactions and point to TCE, as introduced in Section 2.2.1, as a potentially useful theoretical lens for understanding 
implementation in developing country suppliers. Here, we use TCE and the three propositions from Grover and Malhotra (2003) to interpret our findings.

The first proposition from Grover and Malhotra (2003) states that transaction costs are higher under conditions of high asset specificity. An example of a human asset-specific investment in our context is when a buyer educates and trains a supplier's personnel in their code of conduct. This appears to be a common enabler of social sustainability implementation, as evident from Table II. But when a buyer makes such a human capital investment, it cannot be easily redeployed should the supply relationship be terminated. This may explain why buyers are often reluctant to make such investments and have, instead, often relied on monitoring and auditing. This, however, is argued to be a short term approach such human capital investments could actually decrease a buyer's future transaction costs. In terms of physical assets, social sustainability implementation relies, for example, on activities that are costly in the short term, like increasing aisle widths between machinists and providing fire safety equipment. But, again, such physical asset investments can be hugely beneficial in the long term, leading to larger customer orders, increased productivity and better employee retention rates. Unlike human assets, these do not appear highly specific investments, as buyer codes of conduct have similar basic requirements. This may explain why buyers are reluctant to share the costs of such initiatives (see Table II). Overall, our data partly supports Grover and Malhotra's (2003) first proposition: in this context, asset-specific investments mainly relate to human assets. Furthermore, although greater asset specificity may increase transaction costs in the short term, they could contribute to reducing costs in the longer term - this dimension is not captured in the proposition.

The second proposition from Grover and Malhotra (2003) states that bounded rationality and opportunism give rise, under conditions of high uncertainty, to higher transaction costs. Social sustainability implementation features environmental uncertainty because of ex-ante information asymmetry, i.e. an inability to ascertain upfront a supplier's true nature. Direct transaction costs are incurred by the buyer through the initial technical and social audits that support supplier selection, but the quality of the selection decision is bounded and the risk of future losses remains if an inappropriate supplier is chosen. In addition, behavioural uncertainty includes the ex-post costs of monitoring a supplier's social performance and of dealing with opportunistic supplier behaviour. This includes mock compliance, which, if leaked to the media, could result in significant damage to a buyer's reputation. Yet our data suggests that buyers are generally only concerned with their immediate suppliers and not with the compliance of tier-two suppliers, while suppliers themselves may neglect to inform 
buyers that they are subcontracting work or fail to disclose details on their suppliers (like location). Beyond our data, in the case of the Rana Plaza building collapse and both the recent factory fires in Bangladesh, the major buyers - e.g. Benetton, Wal-Mart and Inditex denied knowing their brands were being made in those factories (Bloomberg, 2012, New York Times, 2012, Huffington Post, 2013). They blamed middlemen and suppliers for subcontracting to cheaper, non-compliant factories without their knowledge (Guardian, 2012, BBC, 2013b, Huffington Post, 2013). In conclusion, there appears to be full support for Grover and Malhotra's (2003) second proposition: social sustainability implementation is characterised by high levels of environmental and behavioural uncertainty as well as buyers' bounded rationality and supplier opportunism. This leads to high transaction costs, including monitoring and enforcement costs and indirect costs deriving from reputation damage.

Finally, the third proposition from Grover and Malhotra (2003) focuses on the choice of governance structure. It was suggested that, in general, low transaction costs favour market governance, while high transaction costs favour hierarchical governance. Indeed, our data suggests that a market form of governance is unsuitable due to the high levels of bounded rationality and opportunistic behaviour. Under a pure market governance scenario, a buyer's only supplier selection criterion would be passing the initial audit or conforming to a particular accepted ethical standard, e.g. WRAP. But this leaves a buyer vulnerable to the type of opportunistic behaviour we have described. Instead, a hierarchical governance structure could be more suitable for enforcing socially sustainable practices in developing country suppliers, given the high transaction costs. But an arms-length hierarchical approach was heavily criticised by the four suppliers, while buyers participating in supplier development have been applauded. One of the criticisms of TCE has been that it underplays the impact that trust can have on offsetting the failures of formal contracts and controls (Grover and Malhotra, 2003). Meanwhile, our data suggested, for example, that Buyer 2 became more effective in terms of social sustainability implementation by gaining the trust of its suppliers. Overall, a combination of monitoring and trust building, actively developing and training suppliers, and taking the cultural context into account may be the most efficient way forward. In conclusion, our data partly supports Grover and Malhotra's (2003) final proposition. Social sustainability implementation is characterised by high transaction costs, which calls for vertically integrated forms of governance. But a genuine supplier development and capacity building approach is also needed and is fundamental to achieving a sustainable competitive advantage in the long term. 


\section{Conclusion}

Many Multi-National Corporations (MNCs) are struggling with the social sustainability of their supply chains, particularly when sourcing from developing countries. There has been a need to investigate why some developing country suppliers are adopting socially sustainable practices and how the implementation process is both impeded and facilitated. Prior empirical studies have mainly been in the context of developed countries or focused on the buyer's perspective. In contrast, this paper has presented an exploratory study into social sustainability in the labour intensive Ready Made Garments (RMG) industry of Bangladesh, a developing country. It has combined the perspectives of buyers and suppliers, describing the ground realities of social sustainability. Our findings on the motivators, barriers and enablers of social sustainability are briefly summarised below, while the richness of our data adds to understanding in the literature of the complexities of implementing social sustainability in developing countries. In addition, Transaction Cost Economics (TCE) theory has been used to interpret our findings, which were found to either fully or partially support three propositions on TCE from Grover and Malhotra (2003).

Some of our findings on the motivators, barriers and enablers simply support prior research, but a number of novel factors are also identified (see Table II). For example, we have indentified competition for skilled labour as an important motivator, which - to the best of our knowledge - has not been highlighted previously. The barriers to implementation are often present because codes of conduct do not reflect the local context of Bangladesh. Strictly adhering to the regulations could mean a supplier loses its skilled labour and that children are diverted to other more hazardous industries. Other novel barriers to full implementation relate to the auditing process itself, with friction particularly between suppliers and third-party auditors, mock compliance, and the curious case of buyers overlooking certain violations, suggesting they may be simply interested in market perceptions and not necessarily in genuinely improving supplier conditions. Finally, some of the enablers we have identified could also not be found in the literature, including: adopting a single, industry-wide code of conduct to improve consistency; and, considering the cultural and socio-economic conditions of the developing country during the implementation process.

\subsection{Managerial Implications}

The insights provided can help managers improve the social sustainability of their supply chains. For example, being aware of the key motivators, barriers and enablers may help managers promote good practice and predict the challenges they are likely to face in 
improving the social sustainability of their supply chains, allowing them to be either avoided or overcome. Furthermore, part of our analysis using TCE highlighted the need for buyers to move beyond their immediate suppliers and incorporate second- and possibly third-tier suppliers in the implementation process. This would overcome some forms of opportunistic behaviour, like unauthorised subcontracting, and attenuate transaction costs. Without such steps, more tragedies like the recent building collapse and factory fires are inevitable and buyers will continue to leave themselves vulnerable to reputation damage.

\subsection{Limitations and Future Research}

This paper is based on studying four suppliers and two buyers. Further research is therefore required to determine whether there are other factors relevant to Bangladesh's RMG industry beyond those observed in this limited set of cases. This could involve studying more buyers and suppliers, but also a broader range of stakeholders, including third-party auditors, NGOs, trade associations, workers and government officials. For example, prior literature has indicated that NGOs can act as enablers of sustainability implementation (Maignan et al., 2002, Walker and Jones, 2012), yet the suppliers in our study had a negative perception of the role played by NGOs. This is counter-intuitive and warrants further investigation. For example, perhaps there is a lack of communication between the two parties and a lack of trust, with NGOs seen as a potential threat to future contracts. Standards in second-tier suppliers, which are less visible and likely to lag further behind, could also be investigated. To obtain similarly rich and candid data to that presented here, it would again be important to win the trust and confidence of interviewees.

To add generality to the motivating factors, barriers and enablers identified, a survey of buyers and suppliers could also be conducted. Meanwhile, further motivation for implementation could be generated by quantifying the impact of social sustainability, e.g. via an event study analysis on the share price effects of both bad publicity and launching improvement programmes. Further work could also be conducted to assess the generality of our findings to other manufacturing industries and countries. We might find, for example, that other labour intensive manufacturing industries and countries with similar cultural values and socio-economic conditions face the same sorts of challenges to those identified in Bangladesh’s RMG industry. But it may also be interesting to explore service contexts, which are also typically highly labour intensive but often feature higher levels of visibility and stronger interactions with consumers. 
Finally, we have found TCE to be a useful theoretical lens, but future research could employ other established theories, e.g. stakeholder theory or institutional theory. The former could help to understand the dynamics between stakeholders and the roles they play in social sustainability implementation. The latter could be used to further investigate how internal and external isomorphic pressures influence the propagation of socially sustainable practices across supply chains.

\section{References}

Akhter, S., Salahuddin, A., Iqbal, M., Malek, A. and Jahan, N. (2010), "Health and Occupational Safety for Female Workforce of Garment Industries in Bangladesh", Journal of Mechanical Engineering, Vol. 41 No. 1, pp. 65-70.

Awaysheh, A. and Klassen, R. D. (2010), "The Impact of Supply Chain Structure on the Use of Supplier Socially Responsible Practices", International Journal of Operations \& Production Management, Vol. 30 No. 12, pp. 1246-1268.

Baden, D. A., Harwood, I. A. and Woodward, D. G. (2009), "The Effect of Buyer Pressure on Suppliers in SMEs to Demonstrate CSR Practices: An Added Incentive or Counter Productive?", European Management Journal, Vol. 27 No. 6, pp. 429-441.

Barratt, M., Choi, T. Y. and Li, M. (2011), "Qualitative Case Studies in Operations Management: Trends, Research Outcomes, and Future Research Implications", Journal of Operations Management, Vol. 29 No. 4, pp. 329-342.

BBC, (2013a), "Dhaka Building Collapse: Factories and Buyers", available at: http://www.bbc.co.uk/news/world-asia-22474601, (accessed 29th June 2013).

BBC, (2013b), "Bangladesh Garment Industry Looks to Revive Image", available at: http://www.bbc.co.uk/news/business-21007699, (accessed 2nd October 2013).

Belal, A. R. (2002), "Stakeholder Accountability or Stakeholder Management: A Review of UK Firms' Social and Ethical Accounting, Auditing and Reporting (Seaar) Practices", Corporate Social Responsibility and Environmental Management, Vol. 9 No. 1, pp. 8-25.

Belal, A. R. and Momin, M. (2009), "Corporate Social Reporting (CSR) in Emerging Economies: A Review and Future Direction", in MATHEW TSAMENYI \& UDDIN, S. (Ed.), Accounting in Emerging Economies (Research in Accounting in Emerging Economies, Volume 9), Emerald Group Publishing Limited, pp. 119143.

Beschorner, T. and Müller, M. (2007), "Social Standards: Toward an Active Ethical Involvement of Businesses in Developing Countries", Journal of Business Ethics, Vol. 73 No. 1, pp. 11-20.

Bloomberg, (2012), "Wal-Mart, SEARS Must Put out Factory Fires in Bangladesh", available at: http://www.bloomberg.com/news/2012-12-02/wal-mart-sears-must-put-out-fires-in-bangladesh-factoriesview.html, (accessed 2nd October 2013).

Bryman, A. and Bell, E. (2007), Business Research Methods, Oxford University Press, USA,

Burchielli, R., Delaney, A., Tate, J. and Coventry, K. (2009), "The Fairwear Campaign: An Ethical Network in the Australian Garment Industry", Journal of Business Ethics, Vol. 90 No. 4, pp. 575-588. 
Carter, C. R. and Easton, P. L. (2011), "Sustainable Supply Chain Management: Evolution and Future Directions", International Journal of Physical Distribution \& Logistics Management, Vol. 41 No. 1, pp. 4662.

Carter, C. R. and Jennings, M. M. (2002a), "Logistics Social Responsibility: An Integrative Framework", Journal of Business Logistics, Vol. 23 No. 1, pp. 145-180.

Carter, C. R. and Jennings, M. M. (2002b), "Social Responsibility and Supply Chain Relationships", Transportation Research. Part E, Logistics \& Transportation Review, Vol. 38 No. 1, pp. 37-52.

Carter, C. R., Kale, R. and Grimm, C. M. (2000a), "Environmental Purchasing and Firm Performance: An Empirical Investigation", Transportation Research. Part E, Logistics \& Transportation Review, Vol. 36 No. 3, pp. 219-228.

Carter, C. R. and Rogers, D. S. (2008), "A Framework of Sustainable Supply Chain Management: Moving toward New Theory", International Journal of Physical Distribution \& Logistics Management, Vol. 38 No. 5, pp. 360-387.

Carter, P. L., Carter, J. R., Monczka, R. M., Slaight, T. H. and Swan, A. J. (2000b), "The Future of Purchasing and Supply: A Ten Year Forecast", Journal of Supply Chain Management, Vol. 36 No. 1, pp. 14-26.

Castka, P. and Balzarova, M. A. (2008), "ISO 26000 and Supply Chains--on the Diffusion of the Social Responsibility Standard", International Journal of Production Economics, Vol. 111 No. 2, pp. 274-286.

Ciliberti, F., De Groot, G., De Haan, J. and Pontrandolfo, P. (2009), "Codes to Coordinate Supply Chains: SMEs' Experiences with SA8000", Supply Chain Management: An International Journal, Vol. 14 No. 2, pp. 117-127.

Coase, R. H. (1937), "The Nature of the Firm", Economica, Vol. 4 No. 16, pp. 386-405.

Creswell, J. W. (2009), Research Design: Qualitative, Quantitative, and Mixed Methods Approaches, Sage Publications, Thousand Oaks, Calif.

Dargusch, P. and Ward, A. (2010), "Understanding Corporate Social Responsibility with the Integration of Supply Chain Management in Outdoor Apparel Manufacturers in North America and Australia", International Journal of Business and Management Science, Vol. 3 No. 1, pp. 93-105.

Daugherty, P. J. (2011), "Review of Logistics and Supply Chain Relationship Literature and Suggested Research Agenda", International Journal of Physical Distribution \& Logistics Management, Vol. 41 No. 1, pp. 16-31.

De Brito, M. P., Carbone, V. and Blanquart, C. M. (2008), "Towards a Sustainable Fashion Retail Supply Chain in Europe: Organisation and Performance", International Journal of Production Economics, Vol. 114 No. 2, pp. 534-553.

Dobers, P. and Halme, M. (2009), "Corporate Social Responsibility and Developing Countries", Corporate Social Responsibility and Environmental Management, Vol. 16 No. 5, pp. 237-249.

Ehrgott, M., Reimann, F., Kaufmann, L. and Carter, C. R. (2011), "Social Sustainability in Selecting Emerging Economy Suppliers", Journal of Business Ethics, Vol. 98 No. 1, pp. 99-119.

Eisenhardt, K. (1989), "Building Theories from Case Study Research", Academy of Management Review, Vol. 14 No. 4, pp. 532-550. 
Elg, U. and Hultman, J. (2011), "Retailers' Management of Corporate Social Responsibility (CSR) in their Supplier Relationships - Does Practice Follow Best Practice?", The international review of retail, distribution and consumer research, Vol. 21 No. 5, pp. 445-460.

Elkington, J. (1998), "Partnerships from Cannibals with Forks: The Triple Bottom Line of 21st Century Business", Environmental Quality Management, Vol. 8 No. 1, pp. 37-51.

Emmelhainz, M. A. and Adams, R. J. (1999), "The Apparel Industry Response to "Sweatshop” Concerns: A Review and Analysis of Codes of Conduct", Journal of Supply Chain Management, Vol. 35 No. 3, pp. 5157.

Fox, T. (2004), "Corporate Social Responsibility and Development: In Quest of an Agenda", Development, Vol. 47 No. 3, pp. 29-36.

Gaurdian, (2013), "Bangladeshi Factory Deaths Spark Action among High-Street Clothing Chains", available at: http://www.guardian.co.uk/world/2013/jun/23/rana-plaza-factory-disaster-bangladesh-primark, （accessed 29th June 2013).

Gimenez, C. and Tachizawa, E. M. (2012), "Extending Sustainability to Suppliers: A Systematic Literature Review", Supply Chain Management: An International Journal, Vol. 17 No. 5, pp. 531-543.

Graafland, J. J. (2002), "Sourcing Ethics in the Textile Sector: The Case of C\&A", Business Ethics: A European Review, Vol. 11 No. 3, pp. 282-294.

Grover, V. and Malhotra, M. K. (2003), "Transaction Cost Framework in Operations and Supply Chain Management Research: Theory and Measurement", Journal of Operations Management, Vol. 21 No. 4, pp. 457-473.

Gugler, P. and Shi, J. (2009), "Corporate Social Responsibility for Developing Country Multinational Corporations: Lost War in Pertaining Global Competitiveness?", Journal of Business Ethics, Vol. 87 No. 1, pp. 3-24.

Handfield, R. B. and Melnyk, S. A. (1998), "The Scientific Theory-Building Process: A Primer Using the Case of TQM", Journal of Operations Management, Vol. 16 No. 4, pp. 321-339.

Harrison, J. and Freeman, R. (1999), "Stakeholders, Social Responsibility, and Performance: Empirical Evidence and Theoretical Perspectives", Academy of Management Journal, Vol. 42 No. 5, pp. 479-485.

Hartley, J. (2004), "Case Study Research", in CASSELL, C. \& SYMON, G. (Ed.), Essential Guide to Qualitative Methods in Organizational Research, Sage,London, pp. 323-333.

Hofstede, G. and Hofstede, G. J. (2005), Cultures and Organizations: Software of the Mind: Intercultural Cooperation and Its Importance for Survival, McGraw-Hill, New York, NY.

Hossain, M. M. and Rowe, A. L. (2011), "Enablers for Corporate Social and Environmental Responsibility (CSER) Practices: Evidence from Bangladesh", in WILMSHURST, T. (Ed.), Conference on Social and Environmental Accounting Research (CSEAR), University of Tasmania, Launceston.

Huffington Post, (2013), "In First Interview since Bangladesh Factory Collapse, Benetton CEO Confirms Company's Tie to Tragedy", available at: http:/www.huffingtonpost.com/2013/05/08/benetton-bangladeshfactory-collapse_n_3237991.html, (accessed 29th June 2013).

Huq, S. and Ayers, J., (2008), "Climate Change Impacts and Responses in Bangladesh", available at: http://www.europarl.europa.eu/activities/committees/studies/download.do, (accessed 1st March 2011). 
Hussain, M. F., Moina Hussain, R. A. and Ijaz, R. (2012), "Eastern Perspective of Corporate Social Responsibility: An Exploratory Study", African Journal of Business Management, Vol. 6 No. 3, pp. 11241129.

Illge, L. and Preuss, L. (2012), "Strategies for Sustainable Cotton: Comparing Niche with Mainstream Markets", Corporate Social Responsibility and Environmental Management, Vol. 19 No. 2, pp. 102-113.

Jiang, B. (2009), "Implementing Supplier Codes of Conduct in Global Supply Chains: Process Explanations from Theoretic and Empirical Perspectives", Journal of Business Ethics, Vol. 85 No. 1, pp. 77-92.

Jorgensen, A. L. and Knudsen, J. S. (2006), "Sustainable Competitiveness in Global Value Chains: How Do Small Danish Firms Behave?", Corporate Governance, Vol. 6 No. 4, pp. 449-462.

Klassen, R. D. and Vereecke, A. (2012), "Social Issues in Supply Chains: Capabilities Link Responsibility, Risk (Opportunity), and Performance", International Journal of Production Economics, Vol. 140 No. 1, pp. 103115.

Kleindorfer, P. R., Singhal, K. and Van Wassenhove, L. N. (2005), "Sustainable Operations Management", Production and operations management, Vol. 14 No. 4, pp. 482-492.

Kolk, A. and Tulder, R. V. (2002), "The Effectiveness of Self-Regulation:: Corporate Codes of Conduct and Child Labour", European Management Journal, Vol. 20 No. 3, pp. 260-271.

Kortelainen, K. (2008), "Global Supply Chains and Social Requirements: Case Studies of Labour Condition Auditing in the People's Republic of China", Business Strategy and the Environment, Vol. 17 No. 7, pp. 431443.

Lamberti, L. and Lettieri, E. (2009), "CSR Practices and Corporate Strategy: Evidence from a Longitudinal Case Study", Journal of Business Ethics, Vol. 87 No. 2, pp. 153-168.

Lee, K.-H. and Kim, J.W. (2009), "Current Status of CSR in the Realm of Supply Management: The Case of the Korean Electronics Industry", Supply Chain Management: An International Journal, Vol. 14 No. 2, pp. 138148.

Lim, S. J. and Phillips, J. (2008), "Embedding CSR Values: The Global Footwear Industry’s Evolving Governance Structure", Journal of Business Ethics, Vol. 81 No. 1, pp. 143-156.

Liu, A. M. M., Fellows, R. and Tuuli, M. M. (2011), "The Role of Corporate Citizenship Values in Promoting Corporate Social Performance: Towards a Conceptual Model and a Research Agenda", Construction Management and Economics, Vol. 29 No. 2, pp. 173-183.

Luken, R. and Stares, R. (2005), "Small Business Responsibility in Developing Countries: A Threat or an Opportunity?", Business Strategy and the Environment, Vol. 14 No. 1, pp. 38-53.

Luken, R. A. (2006), "Where Is Developing Country Industry in Sustainable Development Planning?", Sustainable Development, Vol. 14 No. 1, pp. 46-61.

MacCarthy, B. L. and Jayarathne, P. G. S. A. (2011), "Sustainable Collaborative Supply Networks in the International Clothing Industry: A Comparative Analysis of Two Retailers", Production Planning \& Control, Vol. 23 No. 4, pp. 252-268.

Maignan, I., Hillebrand, B. and Mcalister, D. (2002), "Managing Socially-Responsible Buying:: How to Integrate Non-Economic Criteria into the Purchasing Process", European Management Journal, Vol. 20 No. 6, pp. 641-648. 
Malhotra, N. and Birks, D. (2007), Marketing Research: An Applied Approach: 3rd European Edition, Pearson, Essex.

Maloni, M. J. and Brown, M. E. (2006), "Corporate Social Responsibility in the Supply Chain: An Application in the Food Industry", Journal of Business Ethics, Vol. 68 No. 1, pp. 35-52.

Manning, L., Baines, R. and Chadd, S. (2006), "Ethical Modelling of the Food Supply Chain", British Food Journal, Vol. 108 No. 5, pp. 358-370.

Matos, S. and Hall, J. (2007), "Integrating Sustainable Development in the Supply Chain: The Case of Life Cycle Assessment in Oil and Gas and Agricultural Biotechnology", Journal of Operations Management, Vol. 25 No. 6, pp. 1083-1102.

McKinsey, (2011), "Bangladesh Ready Made Garment Landscape", available at: www.mckinsey.com, (accessed 27 October 2012).

Meehan, J. and Bryde, D. (2011), "Sustainable Procurement Practice", Business Strategy and the Environment, Vol. 20 No. 2, pp. 94-106.

Meredith, J. (1993), "Theory Building through Conceptual Methods", International Journal of Operations \& Production Management, Vol. 13 No. 5, pp. 3-11.

New York Times, (2013), "Bangladesh Factory, Site of Fire That Trapped and Killed 7, Made European Brands", available at: http://www.nytimes.com/2013/01/28/world/asia/bangladesh-factory-site-of-fatal-firemade-western-brands.html?_r=5\&, (accessed 2nd October 2013).

Oshri, I., Kotlarsky, J. and Willcocks, L. P. (2011), The Handbook of Global Outsourcing and Offshoring, Pagrave Macmillan, New York.

Pagell, M. and Wu, Z. (2009), "Building a More Complete Theory of Sustainable Supply Chain Management Using Case Studies of 10 Exemplars", Journal of Supply Chain Management, Vol. 45 No. 2, pp. 37-56.

Pagell, M., Wu, Z. and Wasserman, M. E. (2010), "Thinking Differently About Purchasing Portfolios: An Assessment of Sustainable Sourcing", Journal of Supply Chain Management, Vol. 46 No. 1, pp. 57-73.

Park-Poaps, H. and Rees, K. (2010), "Stakeholder Forces of Socially Responsible Supply Chain Management Orientation", Journal of business ethics, Vol. 92 No. 2, pp. 305-322.

Porter, M. E. and Kramer, M. R. (2006), "The Link between Competitive Advantage and Corporate Social Responsibility", Harvard Business Review, Vol. 84 No. 12, pp. 78-92.

Porter, M. E. and Kramer, M. R. (2011), "The Big Idea: Creating Shared Value", Harvard Business Review, Vol. 89 No. 1-2, pp. 63-77.

Powell, W. W. (1990), "Neither Market nor Hierarchy: Network Forms of Organization", Research in Organizational Behavior, Vol. 12 No. pp. 295-336.

Preuss, L. (2001), "In Dirty Chains? Purchasing and Greener Manufacturing", Journal of Business Ethics, Vol. 34 No. 3, pp. 345-359.

Pullman, M. E. and Dillard, J. (2010), "Values Based Supply Chain Management and Emergent Organizational Structures", International Journal of Operations \& Production Management, Vol. 30 No. 7, pp. 744-771.

Quazi, A. M. and O'brien, D. (2000), "An Empirical Test of a Cross-National Model of Corporate Social Responsibility", Journal of Business Ethics, Vol. 25 No. 1, pp. 33-51. 
Reuter, C., Foerstl, K., Hartmann, E. and Blome, C. (2010), "Sustainable Global Supplier Management: The Role of Dynamic Capabilities in Achieving Competitive Advantage", Journal of Supply Chain Management, Vol. 46 No. 2, pp. 45-63.

Rindfleisch, A. and Heide, J. B. (1997), "Transaction Cost Analysis: Past, Present, and Future Applications", the Journal of Marketing, Vol. 61 No. 4, pp. 30-54.

Sarkis, J., Helms, M. M. and Hervani, A. A. (2010), "Reverse Logistics and Social Sustainability", Corporate Social - Responsibility and Environmental Management, Vol. 17 No. 6, pp. 337-354.

Saunders, M., Lewis, P. and Thornhill, A. (2009), Research Methods for Business Students, Prentice Hall,

Seuring, S. and Müller, M. (2008a), "Core Issues in Sustainable Supply Chain Management-a Delphi Study", Business Strategy and the Environment, Vol. 17 No. 8, pp. 455-466.

Seuring, S. and Müller, M. (2008b), "From a Literature Review to a Conceptual Framework for Sustainable Supply Chain Management", Journal of Cleaner Production, Vol. 16 No. 15, pp. 1699-1710.

Seuring, S. A. (2008), "Assessing the Rigor of Case Study Research in Supply Chain Management", Supply Chain Management: An International Journal, Vol. 13 No. 2, pp. 128-137.

Simon, H. A. (1957), Models of Man, Wiley, New York, NY.

Sloan, T. W. (2010), "Measuring the Sustainability of Global Supply Chains: Current Practices and Future Directions", Journal of Global Business Management, Vol. 6 No. 1, pp. 1-16.

Spekman, R. E. and Davis, E. W. (2004), "Risky Business: Expanding the Discussion on Risk and the Extended Enterprise", International Journal of Physical Distribution \& Logistics Management, Vol. 34 No. 5, pp. 414433.

Spence, L. and Bourlakis, M. (2009), "The Evolution from Corporate Social Responsibility to Supply Chain Responsibility: The Case of Waitrose", Supply Chain Management: An International Journal, Vol. 14 No. 4 , pp. 291-302.

Svensson, G. (2009), "The Transparency of SCM Ethics: Conceptual Framework and Empirical Illustrations", Supply Chain Management: An International Journal, Vol. 14 No. 4, pp. 259-269.

Telegraph, (2013), "Tesco Stops Sourcing Clothes from Bangladesh Factory on Safety Fears", availableat: http://www.telegraph.co.uk/finance/newsbysector/retailandconsumer/10122785/Tesco-stops-sourcingclothes-from-Bangladesh-factory-on-safety-fears.html, (accessed 29th June 2013).

Tencati, A., Quaglia, V. and Russo, A. (2008), "Unintended Consequences of CSR: Protectionism and Collateral Damage in Global Supply Chains: The Case of Vietnam", Corporate Governance, Vol. 8 No. 4, pp. 518531.

Tsoi, J. (2010), "Stakeholders' Perceptions and Future Scenarios to Improve Corporate Social Responsibility in Hong Kong and Mainland China", Journal of Business Ethics, Vol. 91 No. 3, pp. 391-404.

Vachon, S. and Klassen, R. D. (2006), "Extending Green Practices across the Supply Chain: The Impact of Upstream and Downstream Integration", International Journal of Operations \& Production Management, Vol. 26 No. 7, pp. 795-821.

Vachon, S. and Klassen, R. D. (2008), "Environmental Management and Manufacturing Performance: The Role of Collaboration in the Supply Chain", International Journal of Production Economics, Vol. 111 No. 2, pp. 299-315. 
Van Teijlingen, E. and Hundley, V., (2001), "The Importance of Pilot Studies", Social research update, available at: http://www.soc.surrey.ac.uk/sru/SRU35.html, (accessed 27 October 2012).

Vasileiou, K. and Morris, J. (2006), "The Sustainability of the Supply Chain for Fresh Potatoes in Britain", Supply Chain Management: An International Journal, Vol. 11 No. 4, pp. 317-327.

Voss, C. (2008), "Case Research in Operations Management", in KARLSSON, C. (Ed.), Researching Operations Management, Routledge, pp. 162-195.

Vurro, C., Russo, A. and Perrini, F. (2009), "Shaping Sustainable Value Chains: Network Determinants of Supply Chain Governance Models", Journal of Business Ethics, Vol. 90 No. 4, pp. 607-621.

Walker, H. and Jones, N. (2012), "Sustainable Supply Chain Management across the UK Private Sector", Supply Chain Management: An International Journal, Vol. 17 No. 1, pp. 15-28.

Welford, R. (2004), "Corporate Social Responsibility in Europe and Asia: Critical Elements and Best Practice", The Journal of Corporate Citizenship, Vol. No. 13, pp. 31-47.

Welford, R. (2005), "Corporate Social Responsibility in Europe, North America and Asia: 2004 Survey Results", The Journal of Corporate Citizenship, Vol. No. 17, pp. 33-52.

Welford, R. and Frost, S. (2006), "Corporate Social Responsibility in Asian Supply Chains", Corporate Social Responsibility and Environmental Management, Vol. 13 No. 3, pp. 166-176.

Werner, W. J. (2009), "Corporate Social Responsibility Initiatives Addressing Social Exclusion in Bangladesh", Journal of Health, Population, and Nutrition, Vol. 27 No. 4, pp. 545-562.

Williamson, O. and Ghani, T. (2012), "Transaction Cost Economics and Its Uses in Marketing", Journal of the Academy of Marketing Science, Vol. 40 No. 1, pp. 74-85.

Williamson, O. E. (1971), "The Vertical Integration of Production: Market Failure Considerations", The American Economic Review, Vol. 61 No. 2, pp. 112-123.

Williamson, O. E. (1975), Markets and Hierarchies: Analysis and Antitrust Implications, Free Press, New York. Williamson, O. E. (1979), "Transaction-Cost Economics: The Governance of Contractual Relations", Journal of law and economics, Vol. 22 No. 2, pp. 233-261.

Williamson, O. E. (1985), The Economic Institutions of Capitalism: Firms, Markets, Relational Contracting, Free Press, New York.

Williamson, O. E. (1996), The Mechanisms of Governance, The Free Press, New York, NY.

Williamson, O. E. (2008), "Outsourcing: Transaction Cost Economics and Supply Chain Management", Journal of Supply Chain Management, Vol. 44 No. 2, pp. 5-16.

Wall Street Journal, (2012), "Bangladesh Fire: What Wal-Mart's Supplier Network Missed", available at: http://online.wsj.com/article/SB10001424127887324024004578169400995615618.html, (accessed 2nd October 2013).

Wu, Z. and Pagell, M. (2011), "Balancing Priorities: Decision-Making in Sustainable Supply Chain Management", Journal of Operations Management, Vol. 29 No. 6, pp. 577-590.

Yakovleva, N., Sarkis, J. and Sloan, T. (2011), "Sustainable Benchmarking of Supply Chains: The Case of the Food Industry", International Journal Of Production Research, Vol. 50 No. 5, pp. 1297-1317.

Yin, R. (2009), Case Study Research: Design and Methods, Sage, Thousand Oaks.

Yu, X. (2008), "Impacts of Corporate Code of Conduct on Labor Standards: A Case Study of Reebok's Athletic Footwear Supplier Factory in China", Journal of Business Ethics, Vol. 81 No. 3, pp. 513-529. 
Table I: Overview of Suppliers and Buyers Interviewed

\begin{tabular}{|c|c|c|c|}
\hline Company & Interviewee(s) & Sector & $\begin{array}{c}\text { Company Size } \\
\text { (Buyers- Sales } \\
\text { Revenue; } \\
\text { Suppliers- } \\
\text { Workforce) }\end{array}$ \\
\hline Supplier A & $\begin{array}{l}\text { Managing Director; } \\
\text { Executive Director; } \\
\text { HRD \& Compliance } \\
\text { Manager }\end{array}$ & $\begin{array}{l}\text { Manufacturing (cutting \& making) - } \\
\text { Knitwear, e.g. t-shirts, } \\
\text { undergarments }\end{array}$ & 700 workers \\
\hline Supplier B & $\begin{array}{l}\text { Managing Director; } \\
\text { Deputy Managing } \\
\text { Director; } \\
\text { HR Manager }\end{array}$ & $\begin{array}{l}\text { Manufacturing (cutting \& making) - } \\
\text { Lingerie }\end{array}$ & 1,500 workers \\
\hline Supplier C & $\begin{array}{l}\text { Group HR \& } \\
\text { Compliance Manager }\end{array}$ & $\begin{array}{l}\text { Manufacturing (cutting \& making) - } \\
\text { sweaters and jeans }\end{array}$ & 2,400 workers \\
\hline Supplier D & $\begin{array}{l}\text { Managing Director; } \\
\text { Chief Operating } \\
\text { Officer; } \\
\text { Compliance Manager }\end{array}$ & $\begin{array}{l}\text { Manufacturing (cutting \& making) - } \\
\text { sweaters }\end{array}$ & 7,000 workers \\
\hline Buyer 1 & $\begin{array}{l}\text { Country Manager; } \\
\text { Supply Chain } \\
\text { Manager; } \\
\text { Compliance } \\
\text { Executive } \\
\end{array}$ & UK Apparel Retailer & $£ 9.74$ billion \\
\hline Buyer 2 & $\begin{array}{l}\text { Senior (Head) } \\
\text { Compliance Officer }\end{array}$ & UK Apparel Retailer & $£ 3.45$ billion \\
\hline
\end{tabular}




\begin{tabular}{|c|c|c|c|c|c|c|c|c|}
\hline & \multirow{2}{*}{$\begin{array}{l}\text { Factors from the Literature } \\
\text { (novel findings unique to our research } \\
\text { marked by } \mathrm{X} \text { ) }\end{array}$} & \multicolumn{6}{|c|}{ Cases Providing Supporting Evidence } & \multirow[b]{2}{*}{ Total } \\
\hline & & Supplier A & Supplier B & Supplier C & Supplier D & Buyer 1 & Buyer 2 & \\
\hline \multicolumn{9}{|l|}{ Motivational Factors } \\
\hline External stakeholder pressure & $\begin{array}{l}\text { Beschorner and Müller (2007); Tencati et } \\
\text { al.(2008); Yu (2008) }\end{array}$ & * & * & * & * & * & * & 6 \\
\hline Owner characteristics & $\begin{array}{l}\text { Baden et al. (2009); Walker and Jones } \\
\text { (2012) }\end{array}$ & * & * & * & * & & & 4 \\
\hline $\begin{array}{l}\text { Competition amongst suppliers for skilled } \\
\text { labour }\end{array}$ & $\mathrm{x}$ & & * & & * & & & 2 \\
\hline Economic Benefits & Tencati et al.(2008) & * & * & * & $*$ & * & * & 6 \\
\hline \multicolumn{9}{|l|}{ Barriers } \\
\hline $\begin{array}{l}\text { Pressure to reduce prices and lack of cost } \\
\text { sharing }\end{array}$ & $\begin{array}{l}\text { Yu (2008); Baden et al.(2009);Walker and } \\
\text { Jones (2012) }\end{array}$ & * & * & * & * & & * & 5 \\
\hline $\begin{array}{l}\text { Confrontational relationships, e.g. between } \\
\text { suppliers and } 3^{\text {rd }} \text { party auditors }\end{array}$ & ( & $*$ & * & * & * & & $*$ & 5 \\
\hline $\begin{array}{l}\text { Suppliers covering up a lack of compliance } \\
\text { - 'mock' compliance }\end{array}$ & $\mathrm{X}$ & $*$ & * & * & * & $*$ & $*$ & 6 \\
\hline $\begin{array}{l}\text { Buyers accepting mock } \\
\text { compliance/overlooking supplier violations }\end{array}$ & $\mathrm{X}$ & $*$ & * & * & * & & & 4 \\
\hline $\begin{array}{l}\text { Misalignment between codes of conduct and } \\
\text { local culture }\end{array}$ & $\mathrm{X}$ & * & * & * & * & & * & 5 \\
\hline $\begin{array}{l}\text { Lack of government support or enforcement } \\
\text { of labour laws }\end{array}$ & Yu, (2008) & * & * & * & * & & * & 5 \\
\hline \multicolumn{9}{|l|}{ Enablers } \\
\hline $\begin{array}{l}\text { Awarding better prices or larger orders to } \\
\text { the most compliant factories }\end{array}$ & Yu (2008); Gugler and Shi, (2009) & * & * & & * & & * & 4 \\
\hline $\begin{array}{l}\text { Having a single industry wide code of } \\
\text { conduct }\end{array}$ & $\mathrm{X}$ & * & & & * & & & 2 \\
\hline $\begin{array}{l}\text { Codes of conduct that reflect culture and } \\
\text { socio-economic conditions }\end{array}$ & $\mathrm{x}$ & & * & * & * & & & 3 \\
\hline $\begin{array}{l}\text { Moving towards supplier development } \\
\text { rather than auditing }\end{array}$ & $\begin{array}{l}\text { Jorgensen and Knudsen (2006); Lim and } \\
\text { Phillips (2008) }\end{array}$ & & * & $*$ & * & & $*$ & 4 \\
\hline Education and training & Boyd et al. (2007); Hall and Matos (2010) & $*$ & & $*$ & & * & * & 4 \\
\hline $\begin{array}{l}\text { Treating suppliers as partners and building a } \\
\text { sense of trust and openness }\end{array}$ & $\begin{array}{l}\text { Lim and Phillips (2008); Tencati et } \\
\text { al.(2008) }\end{array}$ & & * & * & $*$ & & $*$ & 4 \\
\hline Internal codes of conduct for buyers & $\mathrm{X}$ & & & & & * & & 1 \\
\hline Enforcement of the law & Fox (2004); Yu (2008) & * & * & * & & & * & 4 \\
\hline
\end{tabular}

Table II: Key Motivational Factors, Barriers and Enablers from the Case Study Evidence 


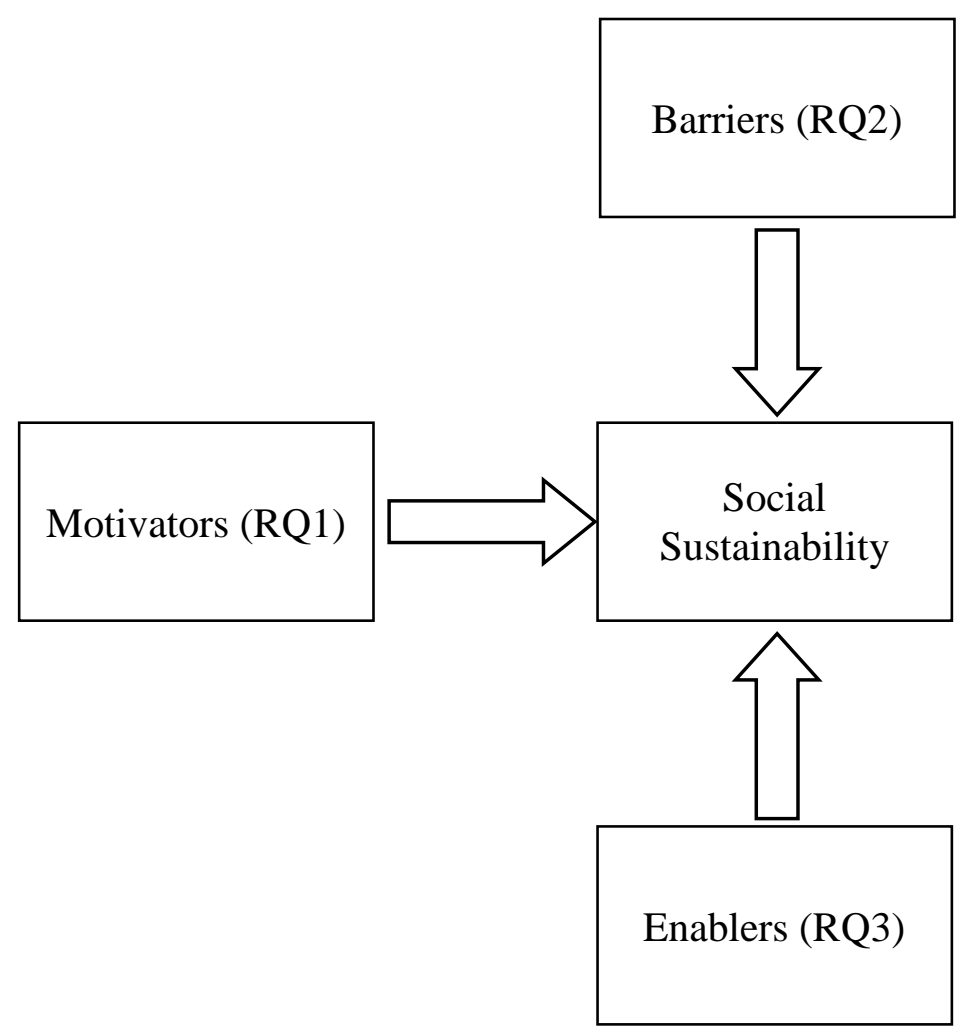

Figure 1: Exploratory Research Framework 